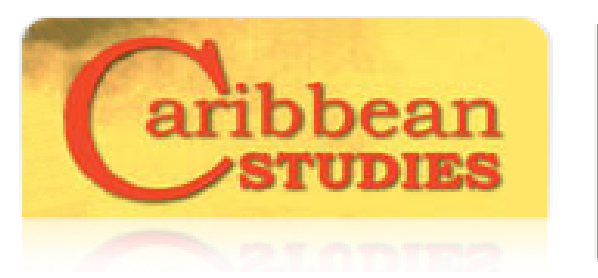

Caribbean Studies

ISSN: 0008-6533

iec.ics@upr.edu

Instituto de Estudios del Caribe

Puerto Rico

Weyland Usanna, Karin

The Absence of an African Presence in Argentina and the Dominican Republic: Caught between

National Folklore and Myth

Caribbean Studies, vol. 38, núm. 1, enero-junio, 2010, pp. 107-127

Instituto de Estudios del Caribe

San Juan, Puerto Rico

Disponible en: http://www.redalyc.org/articulo.oa?id=39220687004

- Cómo citar el artículo

Número completo

- Más información del artículo

- Página de la revista en redalyc.org

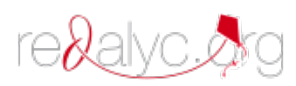

Sistema de Información Científica

Red de Revistas Científicas de América Latina, el Caribe, España y Portugal

Proyecto académico sin fines de lucro, desarrollado bajo la iniciativa de acceso abierto 


\title{
THE ABSENCE OF AN AFRICAN PRESENCE IN ARGENTINA AND THE DOMINICAN REPUBLIC: CAUGHT BETWEEN NATIONAL FOLKLORE AND MYTH
}

\author{
Karin Weyland Usanna
}

\begin{abstract}
This essay analyzes the absence of an African presence in Argentinean and Dominican official history, becoming Blacks assimilated into an homogeneous national culture that not only lacks an African perspective but also a gender one. Through a further analysis of the role of women in current social movements, and the elucidation of a symbolic connection to the domestic struggle and resistance from the part of women during Colonial times, it attempts to unveil this paradox.
\end{abstract}

Keywords: African and Afro-descendent women's resistance and power, Afro-Argentineans, Afro-Dominicans, feminist theory, women's movements

\section{RESUMEN}

Este ensayo analiza la ausencia de la presencia africana en la historia oficial argentina y dominicana, asimilándose los afro-descendientes a una cultura nacional homogénea ausente de una perspectiva africana y una perspectiva de género. A través de un análisis más profundo del rol de las mujeres en movimientos sociales contemporáneos, y la identificación de una conexión simbólica con la lucha doméstica y resistencia por parte de las mujeres durante la colonia, intento develar esta paradoja.

Palabras clave: resistencia y poder de las mujeres africanas y afro-descendientes, afro-argentinos/as, afro-dominicanos/as, teoría feminista, movimientos de mujeres

\section{RÉSUMÉ}

Cet article analyse l'absence de la présence africaine dans l'histoire officielle de l'Argentine et de la République Dominicaine, en mettant en regard les descendants africains et une culture nationale homogène de l'absence d'une perspective africaine et de genre. Le chercheur essaie de démontrer ce paradoxe à travers une profonde analyse du rôle des femmes dans les mouvements sociaux et contemporains, de l'identification d'une relation de lutte domestique et de résistance des femmes durant la période coloniale. 
Mots-clés: résistance et pouvoir des femmes africaines et des descendants africains, afro-argentins/argentines, afro-dominicains/dominicaines, théorie féministe, mouvements des femmes

Received: 1 December 2008 Revision received: 27 October 2010 Accepted: 29 October 2010

\section{Introduction}

7 hroughout my research in recent years in Argentina and the Dominican Republic (2004, 2005a, 2005b, 2006, 2010), I have confronted a similar attitude between these two countries towards the lack of recognition of our African American roots. Despite their major demographic differences, the absence of an African identification in these two countries has raised important theoretical and methodological questions regarding the way we study the role of Blacks and the role of women in the African Diaspora movement in the Americas. Having traveled in 2005 to Buenos Aires, Argentina, my hometown, to attend an Afro-Latino gathering sponsored by GALCI, the Afro-Latino Global Initiative, I realized that official history and in general, Argentina as a nation shares the myth that Blacks have vanished from our past and are no longer part of our present or future. As a child growing up, it never occurred to me to question the ideological foundations of our nation-building discourses, including the myth that Blacks have long disappeared, either killed during the wars of independence or assimilated into a national whitening discourse, embedded in the image of the White countryman figure of el gaucho. ${ }^{1}$ Not surprisingly, these national discourses have had quite an impact in our national building processes, even in provinces like Buenos Aires which had a Black population of $26 \%$ during colonial times and in Córdoba, of $46 \% .^{2}$ This myth is even more paradoxical when we analyze deeper the "invisibility" of Blacks within Argentine popular culture. For example, the first tango titled "el entrerriano" was composed by a Black payador (folk singer) Gabino Eseiza, and our national music, tango, can be traced back to our African roots however it is hardly acknowledged. Anthropologist Dina Picotti (1998) writes that the word tango is derived from the word "nago" or "shango," known in Brazil and Cuba Santería as the African Deity of Thunder and storm. Also the word "milonga" which to Argentineans means a traditional dance, or a neighborhood dance where gossip always reigns, comes from the word "mulunga" which in African means a series of words, gossip, verbal dispute, complaint, or heated discussion (Picotti 1998:105). Likewise, how many times have I walked through the old streets of the city of Buenos Aires, admiring the French and Spanish architecture of 
our national monuments without ever doubting the masculinity and Euro-White ethnicity of our national heroes. Nowadays however, the thin line between reality and myth resonates with Jean Baudrillard's phrase (1978), "Illusion is no longer possible, for reality no longer is." In times when patriarchy, global capitalism and a male national discourse have all reached its peak, the line between fiction and reality becomes more and more diffused, and now we know that history is part of existing mechanisms of dissuasion (1978:19). Likewise, in the Dominican Republic, for example, Dominicans have difficulties today recognizing the origins of the Festivities and rituals of the Brotherhood of the Congo of the Holy Spirit in the African Deity Kalunga, the Goddess of the Ocean and Death in the Congo-Angola region (Hernández-Soto 2004). For example, when filming the video-documentary, Congo Pa'Ti: Afro-Latino Identity in Dominican Culture, I asked about the origin of Kalunga, and most people interviewed in the main park's town of Villa Mella, traditionally known as the "Holy Spirit Savannah," did not know the meaning of the word and only one or two people associated the name with some of the songs played in Congo rituals. These rituals center around the passing over to the world of the dead in order for the ancestors to rest in peace and strengthen the spiritual faith of the community. Most people could not place the name "Kalunga" with the African deities that were disguised in Catholic saints during colonial/modern times. In this sense, erasing the African roots of popular music and religious deities parallels not only the whitening process of Argentinean culture, but also the common practice during Colonial times of erasing the African names and geographical origins of slaves. As it was usually done, adopting the names of their owners most times meant that passing from "slaves" to "Blacks" was a social repositioning adopting the label of "invisible" or "excluded" in the hierarchical Colonial ladder. ${ }^{3}$ The symbolic death of the African presence meant the erasure of one of the most important cultural roots of our national-building processes in the Americas.

In her book, La presencia africana en nuestra identidad (The African presence in our identity), Dina Picotti (1998) writes about the cultural contributions of slaves and free Blacks, and how they have been "assimilated" into national folklore:

In Argentina, stories, poems, sayings, and myths of the slaves are incorporated in the general folklore. There are still caricatures of Blacks, such as in the old carnival dance and music composed by Whites who imitated with laughs the Spanish language of Blacks. In this way, an Afro connotation dominates the popular satire, even though the imitation is no longer associated as such, that is, is misinformed. Afterwards, it becomes part of the written literature, as is the case of the Black poet in the national poem Martín Fierro, assimilated into the gaucho even 
when contributing well-known traditionally African elements such as the call and response known here as "payada" (Dina Picotti 1998:127).

The African roots of our folk tales are not only forgotten, but also the most memorable tales are full of racist slurs and symbolic meaning regarding the position of Blacks in Argentinean culture. For example, one of the most memorable folk tales of the popular poem, Martín Fierro, is precisely the fight between him and a Black man over the latter's partner, a mulatta. Loyal to the Argentinean elite culture, the gaucho Martín Fierro rhymes a couple of phrases to provoke him: "White people were made by God, mulattos, by Saint Peter, and Blacks, by the devil to burn in Hell as charcoal" (Hernández 1958:56-58). The Black man engages in a physical fight with Martín Fierro to defend his honor and dies to Fierro's knife. José Hernández depicts Fierro's pity over the soul of the Black man who cannot rest in peace because he was not given proper burial, and the poem ends, with Fierro's compassion for his soul, feeling compelled to move his body to the cemetery. The symbolic death of the African presence is represented in this folk tale, as well as Fierro's respect over lingering African spirits and a man proper's crossing over to the world of the dead. It is belief in African cosmology that if a proper burial is not given, it would bring bad fate to the community, and more significantly at the time, to the process of assimilation into an Euro-White national imagery. In some parts of the North of Argentina, they still refer to the dead as being in Kalunga, that is, in the cemetery, resting in peace. As I was confronted with two social imaginaries of the "nation" that stood ideologically far from a diversified or hybrid historical recount, ignoring for the most part their African roots and traditions, I could not help thinking whether both "nations" and their subaltern histories and subjectivities were influenced by the same Euro-White male colonial/modern ideology under which Blacks have been excluded from nation-state building processes, along with indigenous and women populations.

Blacks were not the only ones deemed unworthy of incorporation into the emerging national discourses; women were also invisible. The statues in front of the Museum of Man in the Dominican Republic are a case in point. Their visual discourse lacks the representation of women in Dominican history as the indigenous and African presence is mystified in the male figures of Enriquillo and Lemba. These two statues are half naked, invoking the "savage" aspect of slave resistance, as they are both insurgent leaders from the Black and indigenous movements respectively. Sebastian Lemba is known to have led many slave revolts, and Enriquillo is the surname of a rebel indigenous leader, also known as cacique Guarocuya, who in 1520 led a rebellion against the Spaniards that lasted thirteen years until he arrived at a negotiation with Carlos V 
and became Don Enrique. He was assimilated in order for his claims to be heard. Guarocuya is also the main character of the classic historical novel, Enriquillo by Manuel de Jesús Galván (1879) that centers around the killing of several indigenous leaders known as the "matanza de Jaragua" in 1503. Guarocuya was seven years old at the time and as a result, became the symbol of a popular heroe of mixed cultural origins, born to Mencia who after becoming a widow, decides to live amongst Spaniards in behalf of her child. The myth of Guarocuya as the indigenous popular heroe has circulated throughout the Americas, and the Dominican "nation" is proud to celebrate its male assimilated maroon. Galván also wrote about another religious heroe, Bartolomé de Las Casas, who is also immortalized for defending the rights of indigenous people. A Brief History of the Devastation of the Indies (1849) by Bartolomé de las Casas is one of the first-hand documentations narrating the exploitation of indigenous people, hoping that it would touch on the humanitarian side of priests. Today, the modern sculptures of these three heroic masculine figures, Sebastián Lemba, Bartolomé de las Casas and Enriquillo, stand up with their fists up in the air challenging bypassers and school children who weekly visit the official Euro-White dominant male discourses of how the nation was built, inscribed in the national museum of anthropology. ${ }^{4}$

As we can see, folk and myth tales show that both Dominican and Argentineans hold dearest the idea of being White, having a great impact in today's racial aesthetics and social interactions. For example, Dominicans take special considerations for their skin tones and hair texture, and therefore being labeled "Black" stands in sharp contradiction to the dominant racist ideology they have internalized throughout history. ${ }^{5}$ During the dictatorship of Rafael L. Trujillo (1930-1961) the internalization of this state ideology was rather strong, and the 1937 Massacre, killing thousands of Haitians and Haitian-Dominicans living at the borderlands (Turits 2002) is constantly reenacted in day-to-day social interactions. African influence is considered non-Dominican, and therefore, subversive to the state, re-stressing the discourse of the nation as Hispanic, Catholic and White. This social imaginary still stands in opposition to Haitian nationals, the "racial Others" who are identified as Black, "superstitious" and African. ${ }^{6}$ The main intellectual authors of this racist state ideology were Manuel Peña Battle and Joaquín Balaguer, progenitors of trujillismo, whose work throughout the fifties and sixties deepened racism against Haitians and Dominicans of Haitian descent. Today nationalist public functionaries speak of a "pacific invasion" fearing massive migrations of Haitians, ignoring mainly the social and economic contributions of Haitians to the growth and expansion of the sugar industry during the nineteenth century, and to the construction 
industry during the twentieth and twentieth-first century (Silié, Segura and Dore 2002). A recent study on the Dominican population showed racial prejudice visible in state institutions, the family, the economy and in civil society in a country where $80 \%$ of the population is Black or mestizo (Servicio Jesuita a Refugiados y Migrantes 2004, 2005). In an interview with historian Rubén Silié, he states that "In the Dominican Republic there is not really a denial of a Black identity because there was never segregation or persecution of Blacks, but there is a lack of identification with our African roots." Dominicans prefer to call themselves "Indians" instead of "Blacks," and there are several labels such as "Dark Indian," "Light Indian," "Cinnamon Indian" and "Burnt or Ashen Indian," all euphemisms that replace the word "Black" or "Mestizo" when these two words are not used. During Trujillo's regime, the category "Indian" was introduced in people's identification cards. Even today, Dominicans carry their Identification cards with the syllabi "I" for Indian. And until very recent, the letter "N" was forbidden; only occasionally someone may be recorded as "Negro" without the euphemisms. In Argentina, on the other hand, it became lawful in 1778 for slaves to buy their freedom and many male slaves became "peones" and "vaqueros" (manual laborers who handle horses and other animals in rural sites) in the landowners' haciendas in Buenos Aires, La Banda Oriental (Uruguay), Santa Fé, Córdoba and Entre Ríos (Chirino 2005:11). Others enrolled in the army and participated in local and national strategies aimed at the displacement of indigenous populations that prevented local forms of government from emerging, such as Coronel Manuel Roca's campaign in the Patagonia, south of Argentina, at the end of the XIX century. The practice of displacement of indigenous populations where Indians and Blacks have not yet assimilated was in resonance with a phrase coined by one of our founding fathers, Simón Bolívar, "It's better to be colonized by Spain than face massive Black rebellions." Throughout Colonial/ Modern times, and even during and after the Wars of Independence, a fear of Black power was instilled in the social imaginary of the new republics, especially amongst the Criollo class, direct sons and daughters of the Spaniards who held economic and political power by controlling the land, the industries and the new emerging educational institutions. The Generation of 1880 s was best characterized by the social thought of positivist intellectuals who saw in Europe a model for development, such as Faustino Sarmiento in Argentina, and Juan Ramón López in the Dominican Republic, ignoring cultural diversity as an element of the new emerging American nations. ${ }^{\text {? }}$

Therefore, having done research in both countries about the African roots of Dominicans and Argentineans, I could no longer ignore the myth of many of these historical imaginaries carried forth by the long 
sixteenth coloniality/modernity project in contrast to contemporary collective action and social movements. ${ }^{8}$ This paradox raises the question as to how these processes differ from nation to nation. What is the role of women in contemporary social movements as their presence can no longer be ignored, and our African presence no longer denied? Can we speak of a continuum of resistance led by Blacks and women since Colonial times?

\section{Bringing a gender perspective to national discourses and social movements}

Some of these answers may be found analyzing the work of African Diaspora intellectuals such as Paul Gilroy (1992) and Stuart Hall (1991, 1993), as well as third-world writers such as Edward Said, Néstor GarcíaCanclini, Aníbal Quijano, and Homi-Bhaba who have questioned not only the idea of nationalism and the "racialization" of Black, indigenous, and women populations, but also the turn our societies have taken towards global capitalism and the racial hierarchy that sustains it. It is also important to develop a transnational vision where common strategies of political and intellectual resistance could emerge, and trace the impact of the African Diaspora in giving rise to Latin American and Caribbean new republics as we know them today, with their unique languages, cultures and identities. ${ }^{9}$ Today we can agree that numerous conceptual failings had left Afro-descendants, women, and indigenous people invisible or marginalized in relation to dominant narratives and analytical frameworks, without historical specifications and narratives from where to draw cultural, social and political identifications. Such absence makes the task much more challenging.

African-American intellectual Bahati Kuumba (2001) writes about the lack of gender analysis in African and Afro-American social movements of the sixties within a cross-cultural perspective, bringing forth the example of Rosa Park, the African American seamstress who refused to relinquish her seat on the Montgomery City Bus Lines to a White man on December 1, 1955. There were also many instances when AfricanAmerican women spoke out about the oppression and subordination they suffered from their male counterparts in the academy and in the arts, denouncing sexism within their own communities, movements and organizations, such as the case of Alice Walker and Michelle Wright (Walker 1985, Wright 2004). This struggle had great impact on AfroLatina women, and third world women in general (Anzaldúa 1987), as African-American women made themselves heard within and beyond U.S. national borders with a new Diasporic episteme, questioning not only an Euro-White dominant ideology but also a male bourgeois 
perspective best represented in nationalist discourses that excluded them. Feminist Chicana Gloria Anzaldúa's concept of the "new mestiza" is the epitome of this new ethnic and racial consciousness from a gender perspective that questions patriarchal notions from within the Mexican and U.S. nation. In their essay, "Transnational Feminist Cultural Studies" Caren Kaplan and Inderpal Grewal (1999) also emphasize the importance of embracing "gender" in subaltern studies as a crucial category of analysis to understand the "uneven division between men and women, as well as between first and third world constructions of class as inflected by race" (Kaplan and Grewal 1999:353). Furthermore, they discuss the importance of the study of new social movements such as gay liberation in the United States and Europe, indigenous rights in the Americas, and transnational environmental activism, and the new traditions and institutional power that may arise as a result, insofar any particular scholarship does not absorb and appropriate the terms of social critique. They write, "these tensions among methodologies and locations of social critique have implications far beyond their academic manifestations since intellectual contestations over culture impact powerfully though differently across and between public spheres" (p. 353).

On the other hand, Lao-Montes also recognizes the significance of gender in the analysis of Afro-diasporic selves because engendering African Diaspora discourses, he writes, implies "important epistemic breaks and political imperatives" since previous authors have not paid enough attention to "women histories and feminist perspectives" (2007:315). A similar argument about the diversified nature of women's histories and feminisms was made in the eighties by Black feminist writer bell hooks who criticized the lack of diversity and equality in the dominant discourse of White liberal feminism. hooks was neither convinced of the "politics of identity" that followed White liberalism in the eighties and she proposed at this time to move instead towards knowledge production based on a "politics of difference" as a point of departure for the analysis of women's histories and experiences. In order to illustrate this point, in her book, Feminist Theory (2000), hooks embraces the idea of "global sisterhood" based on a mass-based feminist movement where the struggle against white oppression is at the same time a struggle against sexism, as she writes, "when white women attack white supremacy they are simultaneously participating in the struggle to end sexist oppression" (hooks:53-54). Similarly to Patterson and Kelly (2000), hooks defines every day struggle as part of a larger social movement that needs to become mass-based in order for feminist theory and praxis to have an effect on women in general, and particularly on Afro-Latino gender politics and practices. For hooks, as well as many other Latina, Black and third world feminists, racism needs to be a central feminist issue 
because "it is so interconnected with sexist oppression" (p.53). Their answer is to bond on shared strengths and resources as the essence of global sisterhood as opposed to victimization and "common oppression" which was the essence of White feminist liberalism. As bell hooks wrote, "feminist theory would have much to offer if it showed women ways in which racism and sexism are immutably connected rather than pitting one struggle against the other or blatantly dismissing racism" (p.53). In this way, Black feminism shows a real commitment to an international gendered social movement that aims to end sexist oppression. Similar to Lao-Montes (2007) argument of including Afro-Latina identities in contemporary discourses of the African Diaspora, bell hooks had a point when confronting feminist dominant narratives, and instead inserting a new analytical framework and a larger political challenge in the feminist agenda. Contrary to national discourse, we can therefore assert that women have been at the forefront of emerging social movements at home and abroad, in their families and in their communities, reaffirming their African rooted traditions and identities, and gaining at the same time new spaces of negotiation and resistance.

\section{Women's leadership during Colonial times and in today's social movements}

Insofar we have seen that the folklorization of culture, that is the homogenization of a national culture under an Euro-White masculine imagery, has denied the African presence of Latin American nation states, as African cosmology is counter to the idea of assimilation and women are also deemed invisible throughout this process. Mestizaje, or the process by which Blacks, Whites and Indigenous people mixed together and intermarried, has therefore given birth to the idea of a racial democracy, best represented by the saying, "We are all mixed" (Somos una mezcla). The idea of mestizaje has in fact contributed to a romanticized idea of the gaucho or the maroon, these becoming heroes of national folk tales. A more serious look at racial mixing during Colonial times, especially from a gender perspective, is still to be developed. Thus, accepting maroonage culture as the basis of today's social movements is quite a challenge, especially when women have historically led some of these processes, however are absent from national discourses. Some female historians, however, have begun to write about the leading roles of women, in the various mutual aid societies or Black communities also known as quilombos, manieles, palenques or cofradias that were crucial for the survival of runaway slaves, indigenous people, and free Blacks during Colonial times, varying in size and locale. For example, Dominican intellectual Celsa Albert Batista argues that cimarronas or women 
maroons played a big role in the culture of resistance, and she argues that in the Dominican Republic women constituted at least a third of most palenques (Albert 2003:72). Batista also introduces the term "domestic cimarronaje" to refer to women's strategies of resistance in urban spaces applied to "specific actions of slave women that had implications that alter Colonial laws and established norms." She particularly describes the work of the "slave merchants" as they were called by the Crown, who were mostly women whose actions were regulated by Colonial laws in order to limit their freedom as they bought and sold products in the market and created a space for themselves where they could negotiate and interact in social relations considered "dangerous" at the time. For example, the Caroligno Black Code imposed that only free Black men could sell products, and that only slave owners could buy from their slaves the products they produced in order to restrict their free circulation (Albert 2003:76-77). As Albert narrates, other laws also prohibited the union between free Black women and slave Black men because it would contribute to the "insubordination" of the slaves, "mocking and changing legal dispositions" as well as "adopting strategies oriented to convince owners to realize sales and sleep outside of their home." Therefore, a process of creativity and negotiation is introduced by women, regarding "material culture, contributing to the history of Afro-American society and the different alternatives this sector of society developed in order for slaves to gain their freedom" (Albert 2003:79, my translation). Albert mentions "Nanny" as the main woman force in the $18^{\text {th }}$ maroonage culture of Jamaica, and the only female character with a name in the history of Caribbean maroonage. Interestingly enough, "Nanny" is well-known for her magical powers, diminishing in a way the ordinary roles most African women played in the culture of resistance as "rebels" and "fighters" in search of freedom. Scholarly debates have focused less and less on ordinary African women and their struggles, and instead chosen to focus on the male figure and rural or "wild" spaces of cimarronaje or maroonage culture, emphasizing mostly the plantation system as a repeating myth, thus ignoring women's forms of resistance. This in turn has contributed to the idea of "the primitive" and the "wilderness" when it comes to resisting slavery, despite new gender perspectives and historical data on the subject. The plantation/mangrove dichotomized image reinforces the idea that slaves, and particularly women slaves, are incapable of social interactions and therefore, incapable of contributing to society. Pushed to the margins, Cuban writer and professor, Ana Cairo (2005) refers to the existence of a "mental maroonage" when analyzing the novel of Dora Alonso, Ponolani (1966), whose main character was a little girl named Ponolani who was captured in her village in Africa and sold as a slave named Florentina to labor in the Santa Marta sugar 
mill in Guantánamo, Cuba. Every night Ponolani would retell the same stories she heard as a child in her tribe in Africa to her children and the elderly people of the sugar mill, crying herself to sleep. Similar to the concept of freedom developed in Albert's "domestic maroonage," Ana Cairo is able to inscribe a sense of freedom to a female maroonage culture based on the book Ponolani, and she referred to this space as a "mental maroonage," one associated with an internal freedom delimited by a world of dreams that emerge day after day in a life of suffering and misery. Black poet Nancy Morejón had already identified this new gender perspective on maroonage and freedom when publishing her poem, "Mujer Negra" (1944), combining the spirit of maroonage with the independence winds preceding the Cuban revolution in the late fifties. Another example of female slave culture that represents a locale between Albert's and Cairo's idea of "domestic" and "mental" maroonage is the book by Cuban historian, Daisy Rubiera Castillo (1997), Reyita, sencillamente, narrating the life of her own grandmother, Reyita, daughter of slaves. This book gives us elements to construct a "new" gendered and racial imaginary as Reyitas' testimony speaks out about the struggle she put up when growing up in Cuba during the late nineteenth century and early twentieth century, scorned by her own family for being "negrita" and lied to by her own husband into a fake marriage as it turned out she was her second wife. Reyitas' involvement in the Black Star Movement during the 1940s shows the courage and pride she held for her own race and promise of Africa as her homeland.

Following the footsteps of their ancestors, Black women in Argentina and the Dominican Republic are the ones leading today's social movements, not only regaining back their space and African female voice but also working from community and domestic spaces, as they did during Colonial times. For example, the director of La Casa IndoAfroamericana, Lucía Molina, has led several local struggles for the past twenty years working with youth at risk in the town of Santa Fe, several hundred miles north of Buenos Aires. Her goal has been to work towards identity affirmation and cultural rights, as she developed a theatre and dance group composed of adults and youth who reenact the history of Blacks in Argentina. During her opening remarks at the GALCI meeting in Buenos Aires to an audience of three hundred people or more, she explained how difficult it is to always be seen as a foreigner in your own home: "I'm always asked the question: Where are you from? Even though this is a very simple question, it violates one of our basic human rights, the right to an identity." During my stay in Buenos Aires, Argentina, for the GALCI conference, I met several Afro-Latina activists, intellectuals, and community leaders, like Lucía Molina, who are willing to take their long standing activism to the larger international scenario 
because locally their demands meet deaf ears. While witnessing their perseverance and strength, I could not help wondering if that same quest for injustice and recognition led "Nanny" to stand up for her own beliefs or Rosa Park to sit in the white section of the bus, provoking the spurs of rebellion and social transformation. As Lucía Molina continues, "by educating ourselves and others, we do not feel ashamed of whom we are, and we hope that the surrounding society begins to see us differently." Pushed to the margins, Afro-Latina women are rebelling to the cycle of victimization and oppression their ancestors lived through.

Pocha is another Afro-Latina woman activist, founder and director of África Vive, who does community work in La Matanza and other predominantly Afro-descendant populations in Argentina, trying to unify Afro-Argentinean families who were displaced from their homes and communities. This was the story of the afro-descendant family we visited with GALCI organizers in La Matanza, as residents explained "they brought us here far away from the city. In a way it was good because they gave us cement houses with floors, the ones we left behind were made of zinc and had dirt floors, however we all ended up in different places. Pocha is now beginning to gather us and this is how we are learning about our African ancestry and our rights." When asked about the three most important community priorities, residents answered that they were most concerned with unemployment, drugs, and school desertion. These data coincide with other statistics that point to the fact that ninety percent of the Afro-descendant population in Latin America is poor, emphasizing the close relationship between institutionalized racism and poverty. Insofar, we have suggested here that this situation has been the direct result of the denial of an African heritage and a general lack of recognition of African cultural traits and contributions to Latin American national identity and culture. Likewise, two of the major challenges La Casa faces today are poverty and school desertion. La Casa focuses on youth "at risk" because this is a community priority, not letting youth fall "outside of the system," becoming a growing statistics of Afro-descendant youth in jail.

As it became clearer at the GALCI meeting, the main question for the Argentinean case is recognition and acknowledgement, including the question what has happened with the afro-descendant population that in colonial times represented quite a large amount. As testimonies flourished among the participants, it was publicly recognized that Blacks have been "erased" from the history of the Argentinean nation, as Professor Alejandro Solomianski from the University of California also stated in his opening remarks at the GALCI meeting: "The Argentinean case is unique and surprising because it was able to erase from its history all the contributions that Blacks made to this country." ${ }^{10}$ A young participant 
at the conference seemed to confirm this was true in school curricula and official discourses: "When I was in high school my teacher said in class that all Black people had been killed in the War with Paraguay and I raised my hand and said that I was Afro-descendant and belonged to $L a$ Casa. She was so surprised that I had stood up and said it. I was trying to be polite because I didn't want to end up with a bad grade (Laughter)." Another testimony from one of $\mathrm{La}$ Casa's community leader asserts this lack of knowledge about African roots in Argentinean families: "We repeatedly tell our youth that they are afro-descendant; nobody gave us this information to our generation when we were growing up. I discovered I was afro-descendant when I went to Spain and saw a picture of my grandmother. In Argentina, even when families know about their African ancestry, they are ashamed to recognize it. They just won't do it and it becomes a family's well kept secret." ${ }^{11}$ Hopefully, this process of self-recognition will bring people and grassroots organizations together under the realization that identity and power, cultural affirmation and action are intertwined, and are part of the same struggle. It is also important to recognize that only recently, culture and identity have become the basis for claims against the state in Latin America and the Caribbean, in part as a result of international organizations' pressure on local governments to begin changing their policies and recognize instead the effects of racism and oppression in their cultural, social and political institutions and practices, as the 2001 Durban Declaration stipulated. Still in 2004, in an interview I conducted with the Subsecretary of the Museum of Dominican Man, José Guerrero, he expressed that "the Dominican Republic is probably the only country in the world where Blacks do not want to be called Blacks." Likewise, Argentineans are very proud of their Euro-White ancestry, bringing it forward at every opportunity.

It seems then that there is not only the challenge of stepping out of a Black invisibility but also the challenge facing Afro-descendant community organizations, activists and intellectuals in reversing the internalization of an Euro-White imagery, deeply embedded in racial mixing and social interactions. This process of reversal has been particularly difficult for Argentina who besides their native Black population, located mainly in the North of Buenos Aires, is composed of other ethnic Black groups such as the Cabo-Verdians, Afro-Ecuadorians, and more recently, since the 1990s, a community of African citizens mainly from Nigeria. It is therefore more challenging to face a diverse Black community composed of recent migrant groups, such as is also the case in the Dominican Republic when analyzing Haitian/Dominican relations. It seems that in both places the "other" is now the exclusion of the "African" migrant, instead of looking within, into the native population. Furthermore, Afro-descendant communities in both countries have their 
own history and trajectory, and due to the various ethnic origins and cultures, coming together as one single Afro-Diasporic group has been difficult. At the GALCI meeting this issue was addressed, and in the case of Argentina, the long-time collaboration between La Casa, África Vive, the Cabo-Verdian community, and Uruguayan organization, Afro-Mundo was acknowledged. The more recent groups, such as the Africans and the Afro-Ecuadorians, however seemed a bit more isolated. The smaller number of people in these groups as well as their focus on economic mobility rather than community organizing were mainly the causes of their desegregation. In fact, while we were at the GALCI gathering, the Afro-Ecuadorian group lost the renting of a full house in San Telmo because they could not afford to pay the rent. The sad thing though was that the house was used as a cultural center and ethnic restaurant, losing at the same time a resourceful cultural affirmation space and economic niche. On the other hand, the Nigerian community is composed mainly of independent merchants who sell clothes, sneakers, and watches on the streets, having community leaders and academics a difficult time bringing them together as one group over a single issue or concern. Nonetheless, a united front is necessary when it comes to exercising economic and political rights and negotiating with local governments at home or at international conferences. The indigenous movement, on the other hand, has been able to achieve a much higher level of unity and grass-root organizing among different indigenous tribes in the Americas, gathering themselves in international summits, forums and world conferences (Becker 2008). International agreements and declarations are therefore useful as long as capable social actors of civil society can implement them at a local level without losing their original initiatives and agendas as they develop transnational alliances and become more and more integrated into the public spheres and discourses of cultural, economic and political institutions at large. In the case of the Afro-descendants populations of the Americas, these efforts would strengthen a single Diasporic Afro-Latino/American movement, creating at the same time an "intermediate public space," providing Black women and men visibility in the global-local roundtable of political decision-making. In the last few years, due to pressure from international organizations such as the United Nations and world-wide social forums, there have been efforts on the part of governments and other agencies to acknowledge the relationship between colonialism, race and poverty (Santos 2004), and this has resulted to the advantage of Afro-descendant populations and organizations in the Americas. More work in this direction though needs to be organized and strategically carried out by community leaders to transform what could be called "domestic/mental maroonage" strategies into effective public policies. 
In the Dominican Republic, on the other hand, few organizations address the issue of racism due to social and economic marginalization. The Red de Mujeres Negras and Casa por la Identidad de las Mujeres Afro were groups that had the most impact at a local level in terms of advocacy and networking. Their members adhered to the feminist movement, and also acted separately, according to their "racial" and other "identities" when pushing for media campaigns and other efforts against racism. ${ }^{12}$ However due to the lack of resources and state support as well as the emigration of some of its members, these groups are no longer active. Another group in the Dominican Republic that has been very assertive in terms of the Afro-descendant struggle is the Dominican/Haitian Women's Movement (MUDHA-Movimiento de Mujeres DomínicoHaitianas) that has also worked hand in hand with the feminist movement, however due to their Haitian status, they have felt at times isolated and marginalized, as they have run higher risks of getting deported, as Sonia Pierre, the director of MUDHA said: "This is not a risk Dominican feminists take when they assert their Black identities, but we do." It seems that race, gender and politics do not always go hand in hand, and resonating with the work of bell hooks, more support has to be given to Afro-Latino women in their struggle to end racism, as gender and racial analysis becomes at the forefront of international agendas and day-to-day confrontations in terms of existing national discourses that go counter to the exertion of universal rights for all people.

\section{Conclusion}

In sum, more studies are needed comparing women's idea of freedom during colonial times and today's global framework of Afrodescendent social movements where women play an important role. In her recent work, Ginetta Candelario (2008) used the common phrase, "Black behind the ears" that is, where no one can see it, as the underlying theme on various essays on racial diversity in the Dominican Republic and the United States. Her discussion on public spaces such as museums and beauty parlors show us the day-to-day norms that reinforce an Eurowhite image tied to the concept of national identity as a social construct. In his work, El retorno de las yolas, Silvio Torres-Saillant (2004) has also pointed out the resistance towards embracing a diversified plural concept of the "nation" and particularly he denounces the complicity of most Dominican intellectuals in having contributed or built a comfortable ideological position from "within" the nation. It becomes clear that due to an ideology of Euro-white assimilation tied to the social imaginary of an Euro-white nation, Dominicans and Argentineans continue to label and identify each other based on racial pure forms instead of hybrid ones 
under a modern/colonial ideology. It is therefore important to study the different social contexts and historical moments where these processes are reinforced and through which race and racial relations have been crucial for the reproduction of racism, race thinking and race acting, calling not only for a thorough study of "the world racial situation that succeeded the abolition of slavery" (Winant 2001:8), but also a greater sensitivity to "everyday forms of resistance, accommodation, and opposition" (Mintz 1974:28). Furthermore, it is important to have this particular look on history from a gender perspective, as we already discussed how Afro-Dominican and Afro-Argentinean women have played an important role in identity-community formation practices and new social movements since Colonial times. Despite these efforts, they have been excluded from their national histories and contemporary discourses, not being able to break away from identities that reproduce a system of racial and gender exclusion. As we burn the lines between myth and reality in the official history of many Latin American and Caribbean nations today, we can begin to open ourselves to a hybrid Afro-Diasporic vision of the Americas and close the gap between myth, folklore and social history. It is important then to deconstruct and unravel the racial/gender hierarchies and structures that have maintained pure forms of identification along well defined patterns of inclusion and exclusion; for it is at this crossroad, between reality and illusion, where patriarchy collapses with the consumption of an homogeneous Euro-White global culture.

\section{Notes}

1 The word "gaucho" is the local name for "paisano" or "native," and makes reference to someone who works in the Argentinean pampas (countryside), with their own language, work and customs. In 1926, Uruguayan intellectual Vicente Rossi criticizes the way that gaucho literature created this character versus the one who works and lives in harsh conditions in the countryside, a "silent man of fight" he called it.

2 In his work, "Los africanos en la región," journalist José Alberto Chirino (2005) makes reference to Arcondo (1998) and Furlani (1996) whose work provides the numbers of slaves in the Colonial Registry of 1778 of the Province of Córdoba (empadronamiento de 1778) and later on in 1799 in the Census of the same province. According to this data, by the end of $18^{\text {th }}$ century there were in 1778 , 5,569 slaves ( $12.5 \%$ of the total population), and in 1799 , there 
were 21,230 Blacks (6,338 slaves and 14,892 free Blacks), 17,340 Spaniards, and 5,482 Indigenous people.

3 Chirino (2005) describes this process of social repositioning as another way of giving Africans during Colonial time the mechanisms for creating a "genealogy of the subaltern" that is filtered into the new socio-economic and political reality after slavery is abolished and Argentina welcomes mass waves of European immigrants.

4 For a discussion of space and image of the Dominican Museum of Man, see Candelario 2008.

5 For the analysis of racial construction in the Dominican Republic, see Howard, D. (2001), Torres Saillant, S. (1998) and Sagás, E. (2000).

6 For the study of race and Haitian migrants and their descendants, see Wooding, B. and Moseley-Williams, R. (2004), and for the study of Haitian/Dominican historical and contemporary relations see Wucker (1999) and Duany (2006).

7 For a historical account of the "uncertain" indigenous origins of one of Argentinean national independence heroes, San Martín, and how his plans for an Inca Republic, and the creation of an Inca Monarchy were diffused, see Chumbita, 2001: pp. 158-173.

8 For the meaning and genealogy of the term "modern/colonial" see Grosfoguel and Cervantes Rodríguez 2002, Quijano 2000 and Mignolo 2000. It alludes to the fact that "coloniality" is born out of the project of modernity born in the $16^{\text {th }} \mathrm{ct}$.

9 This is not to say that all Caribbean nations gained their independence in the early period of the $19^{\text {th }}$ century, however the Spanish speaking Caribbean, except for Puerto Rico and Cuba, as well as the Southern Cone were indeed part of this earlier independence period. For an account of how Africans have affected the major developments of the New World and how they were affected by them, see Andrews (2004).

10 Opening remarks at the GALCI (Afro-Latino Global Initiative) gathering, Buenos Aires, Argentina, August 2005.

11 These quotes are documented in the video-documentary, "AfroArgentinos/as: El estatus de las comunidades afro-descendientes en las Américas" produced by the Melassa Foundation, Santo Domingo, Dominican Republic, 2005. 
12 See Ochy Curiel (2004), "Identidades esencialistas o construcción de identidades políticas: El dilema de las feministas." In this article, former member of the Black Women's Network, Ochy Curiel raises the question, how to break away from identities that do not lead to political strategies and continue to exclude and reproduce a system of exclusion and stereotypes, particularly within the feminist Latin American movement. Also see Mendoza, 1997a and 1997b.

\section{References}

Arcondo, A. 1998. "La población de Córdoba según el empadronamiento de 1778." Serie de Estudios no. 27. Universidad Nacional de Córdoba: Instituto de Economía y Finanzas, Facultad de Ciencias Económicas.

Albert Batista, C. 1990. Mujer y esclavitud en Santo Domingo. Santo Domingo, República Dominicana: Ediciones INDAASEL, 2003.

Andrews, G.R. 2004. Afro-Latin/American. New York and London: Oxford University Press.

Anzaldúa, G. 1987. Borderlands / La Frontera: The New Mestiza. San Francisco: Aunt Lute Books.

Baudrillard, Jean. 1978. Cultura y simulacro. Traducción, Editorial Kairós, cuarta edición, 1993.

Becker, M. 2008. "Third Continental Summit of Indigenous Peoples and Nationalities of Abya Yala: From Resistance to Power." Latin American and Caribbean Ethnic Studies 3 (1):85-107.

bell hooks. 2000. Feminist Theory: From Margin to Center. $2^{\text {nd }}$ edition. London: Pluto Press.

Bhabba, H. 1994. The Location of Culture. London: Routledge.

Cairo, A. 2005. Bembé para cimarrones. La Habana, Cuba: Publicaciones Acuario, Centro Félix Varela.

Candelario, G. 2008. Black Behind the Ears: Ambiguity and Blackness in Dominican Identity Displays. Durham, NC: Duke University Press.

Chirino, J.A. 2005. "Los africanos en la región.” Paper presented at the III Regional Congress of History, City of Villa María, Córdoba, Argentina.

Chumbita, H. 2001. El secreto de Yapeyú: El origen mestizo de San Martín. Buenos Aires, Argentina: Ediciones EMECE.

Curiel, O. 2004. "Identidades esencialistas o construcción de identidades políticas: El dilema de las feministas." Pp. 79-119 in Miradas desencadenantes: Los estudios de género en la República Dominicana al inicio del Tercer Milenio, edited by G. Candelario. Santo Domingo, República Dominicana: Instituto Tecnológico de Santo Domingo (INTEC). 
de Jesús, Galván, M. 1849. Enriquillo. Santo Domingo, República Dominicana: Susaeta Ediciones Dominicana.

Duany, J. 2006. "Racializing Ethnicity in the Spanish-speaking Caribbean: A Comparison of Haitians in the Dominican Republic and Dominicans in Puerto Rico." Latin American and Caribbean Ethnic Studies 1 (2):231-248

Furlani, A. 1996. "Apuntes y reflexiones para una historia de Yucat.” Manuscript.

García-Canclini, N. 1989. Culturas híbridas: Estrategias para entrar y salir de la modernidad. México: Editorial Grijalbo.

Grosfoguel, R. and A.M. Cervantes-Rodríguez. 2002. The Modern/Colonial Capitalist World System in the Twentieth Century: Global Processes, Antisystemic Movements, and the Geo-Politics of Knowledge. Boulder: Paradigm Press.

Hall, S. 1993. "Cultural Identity and Diaspora.” Pp. 392-403 in Colonial Discourse and Post-Colonial Theory, edited by Patrick Williams and Laura Chrisman. London: Harvester.

1991. "Old and New Identities." Pp. 19-40 in Culture, Globalization and the World-System, edited by Anthony D. King. Binghamton: State University of New York Press.

Hernández, José. 1958. Martín Fierro. España: Editorial Losada, edición 30, 2000.

Hernández Soto, C. 2004. Kalunga Eh! Los Congos de Villa Mella. Santo Domingo, República Dominicana: Editorial Letra Gráfica.

Howard, D. 2001. Colouring the Nation: Race and Ethnicity in the Dominican Republic. Boulder, CO: Lynne Rienner.

Kaplan, C. and I. Grewal. 1999. "Transnational Feminist Cultural Studies: Beyond the Marxism/Postructuralism/Feminism Divides." Pp. 349-363 in Between Woman and Nation: Nationalisms, Transnational Feminisms, and the State, edited by C. Kaplan, N. Alarcon and M. Moallem. Durham: Duke University Press.

Kuumba, B. 2001. Gender and Social Movements. New York: Altamira Press.

Lao-Montes, A. 2007. "Decolonial Moves: Trans-locating African Diaspora Spaces." Cultural Studies 21 (2-3):309-338.

Mendoza, B. 1997a. Memoria de los Seminarios Racismo en la educación. Casa por la Identidad de las Mujeres Afro. Santo Domingo, República Dominicana: Servicio Gráfico Ce-Mujer.

1997b. Memoria del Foro Por una sociedad libre de prejuicio racial. Casa por la Identidad de las Mujeres Afro. Santo Domingo, República Dominicana: Editora Búho.

Mignolo, W. 2000. Local Histories/Global Designs: Coloniality, Subaltern Knowledges and Border Thinking. New Jersey, Princeton University Press.

Mintz, S.W. 1974. Caribbean Transformations. Chicago, IL: Aldine.

Picotti, D. 1998. La presencia africana en nuestra identidad. Buenos Aires, Argentina: Ediciones del Sol, Serie Antropológica. 
Quijano, A. 2000. "Coloniality of Power, Eurocentrism, and Latin America." Nepantla 1 (3):139-155.

Rubiera, C.D. 1997. Reyita, sencillamente. La Habana, Cuba.

Sagás, E. 2000. Race and Politics in the Dominican Republic. Gainesville: University Press of Florida.

Santos, B. de S. 2004. "El Foro Social Mundial: Hacia una globalizacion contrahegemónica." Pp. 330-343 in El Foro Social Mundial: Desafiando Imperios, edited by J. Sen, A. Anand, A. Escobar and P. Waterman. Málaga: El Viejo Topo.

Servicio Jesuita a Refugiados y Migrantes. 2005. 17 opiniones sobre racismo en República Dominicana, edited by B. García. Santo Domingo, República Dominicana: Impresora Azteca.

2004. La actitud racial en República Dominicana. Santo Domingo, República Dominicana: Impresora Metropolitana.

Silié, R., C. Segura and C. Dore. 2002. La nueva inmigración haitiana. Santo Domingo, República Dominicana: Flacso.

Torres, Saillant, S. 2004. El retorno de las yolas: Ensayos sobre diáspora, democracia y dominicanidad. Santo Domingo, República Dominicana: Editorial Manatí y Librería La Trinitaria.

Turits, R. 2002. The Foundations of Despotism: Peasants, the Trujillo Regime and Modernity in Dominican History (1930-1961). California: Stanford University Press.

Walker, A. 1985. The Color Purple. New York: Pocket Books.

Weyland, K. 2010. Cross-over and B(l)ack: The African Roots of Argentinean Culture. Video-documentary, Melassa Films.

2006. Negociando la aldea global con un pie aquí y otro allá: La diáspora femenina dominicana y la transculturalidad como alternativa descolonizadora. Santo Domingo, República Dominicana: INTEC y Academia de Ciencia de la República Dominicana.

2005a. "Género y transnacionalismo en la encrucijada de agendas locales y globales: De Nueva York a Villa Mella.” Pp. 209-230 in Miradas desencadenantes: Los estudios de género en la República Dominicana al inicio del Tercer Milenio, editado por G. Candelario. Santo Domingo, República Dominicana: INTEC.

2005b. Afro-Argentines: The Status of Afro-Descendants Communities in the Americas. Video-documentary. Melassa Films and GALCI (Afro-Latino Global Initiative).

2004. Congo Pa'Tí: Afro-Latino Identity in Dominican Culture. Video-documentary. Santo Domingo, República Dominicana: Fundación Melassa.

Winant, H. 2001. The World is a Ghetto: Race and Democracy since World War II. New York: Basic Books. 
Wooding, B. and R. Moseley-Williams. 2004. Needed but Unwanted: Haitian Immigrants and their Descendants in the Dominican Republic. London: Catholic Institute for International Relations.

Wright, M. 2004. Becoming Black: Creating Identity in the African Diaspora. Durham: Duke University Press.

Wucker, M. 1999. Why the Cocks Fight: Dominicans, Haitians and the Struggle for Hispaniola. New York: Hill and Wang. 